\title{
Distribution and Relative Abundance of Richardson's Ground Squirrels, Urocitellus richardsonii, According to Soil Zones and Vegetation Height in Saskatchewan During a Drought Period
}

\author{
Gilbert ProulX, Keith MacKenzie, and Neil MacKenzie
}

\author{
Alpha Wildlife Research \& Management Ltd., 229 Lilac Terrace, Sherwood Park, Alberta T8H 1W3 Canada
}

Proulx, Gilbert, Keith MacKenzie, and Neil MacKenzie. 2012. Distribution and relative abundance of Richardson's Ground Squirrels, Urocitellus richardsonii, according to soil zones and vegetation height in Saskatchewan during a drought period. Canadian Field-Naturalist 126(2): 103-110.

Richardson's Ground Squirrels (Urocitellus richardsonii) prefer to establish their burrow systems in fields with shorter vegetation and good visibility. Between 2001 and 2009, warm weather and low precipitation, creating ideal environmental conditions for this species, were common throughout Saskatchewan. We therefore hypothesized that Richardson's Ground Squirrels would be abundant throughout the agricultural region of the province and would be relatively more abundant in fields with shorter vegetation. In May and June 2008, we selected a total of 36 study plots of 0.49 ha each in 12 randomly selected rural municipalities in the Brown, Dark Brown, Black, and Gray soil zones. Using visual counts of Richardson's Ground Squirrels and counts of burrow entrances, we found that Richardson's Ground Squirrels were abundant across the agricultural region of the province, but densities of Richardson's Ground Squirrels and densities of burrow entrances were generally higher in the drier Brown soil zone than in the other soil zones. In 2009 and 2010, in a study of the effect of vegetation height on the abundance of Richardson's Ground Squirrels in the Brown soil zone, we found that densities of burrow entrances in five study plots with vegetation $\geq 15 \mathrm{~cm}$ in height were significantly $(P<0.05)$ lower than densities recorded in five adjacent study plots with vegetation $<15 \mathrm{~cm}$ in height. Our findings warrant more studies on Richardson's Ground Squirrels inhabiting fields with short and tall vegetation to determine whether differences in population densities are due to differences in birth and death rates or immigration and emigration.

Key Words: Richardson's Ground Squirrel, Urocitellus richardsonii, Spermophilus richardsonii, distribution, drought, Saskatchewan.

Drought is a chronic concern in the Canadian prairies (Liu et al. 2004), and, according to Phillips (2002), it had never been as serious or extensive as in 2001. Drought depresses plant growth (Heath et al. 1973; Glickman 2000) and creates ideal conditions for Richardson's Ground Squirrels (Urocitellus richardsonii, changed from Spermophilus richardsonii on the basis of craniometric analyses by Helgen et al. 2009), which prefer to establish their burrow systems in fields with shorter vegetation and good visibility (Yensen and Sherman 2003).

Across the prairies, soil zones are classified as Brown, Dark Brown, or Black according to the type of chernozemic soils dominating the particular zone (Figure 1), i.e., the amount of soil organic matter content and color of the surface soil horizons (Pennock 2005*; Fuller 2010). In the northern regions, soils that have somewhat lighter-coloured surface horizons than the Black soils are classified as Gray (Figure 1), and are characteristic of soils developed in a transitional environment between grassland and forest (Pennock 2005*). On the basis of telephone interviews, the Provincial Council of Agriculture Development and Diversification Boards and the Sustainable Production Branch, Saskatchewan Agriculture and Food $\left(2001^{*}\right)$ concluded that soil zones have a bearing on the distribution of Richardson's Ground Squirrels in the province: Richardson's Ground Squirrels were more common in the Brown and Black soil zones, and they were less frequent in the Dark Brown and Gray soil zones.

It appears that vegetation height can also have an impact on the density of Richardson's Ground Squirrels. In Alberta, Downey et al. (2006) found that Richardson's Ground Squirrels avoided pastures with grass $>30 \mathrm{~cm}$ in height.

The first objective of this study was to determine the distribution of Richardson's Ground Squirrel populations across the soil zones of Saskatchewan during a drought period and the relative density of each population. Since warm weather and low precipitation were common throughout Saskatchewan from 2001 to 2009 (Proulx 2010), we expected that vegetation would be short in grasslands and pastures in all soil zones and we hypothesized that Richardson's Ground Squirrels would be abundant throughout the agricultural region of the province. The second objective was to correlate the relative densities of Richardson's Ground Squirrels in fields with different vegetation heights within a single soil zone. We hypothesized that Richardson's Ground Squirrels would be relatively more abundant in fields with shorter vegetation.

\section{Study Area}

The study of Richardson's Ground Squirrel populations was conducted in the diverse soil zones of the province's agricultural region, which is primarily found 


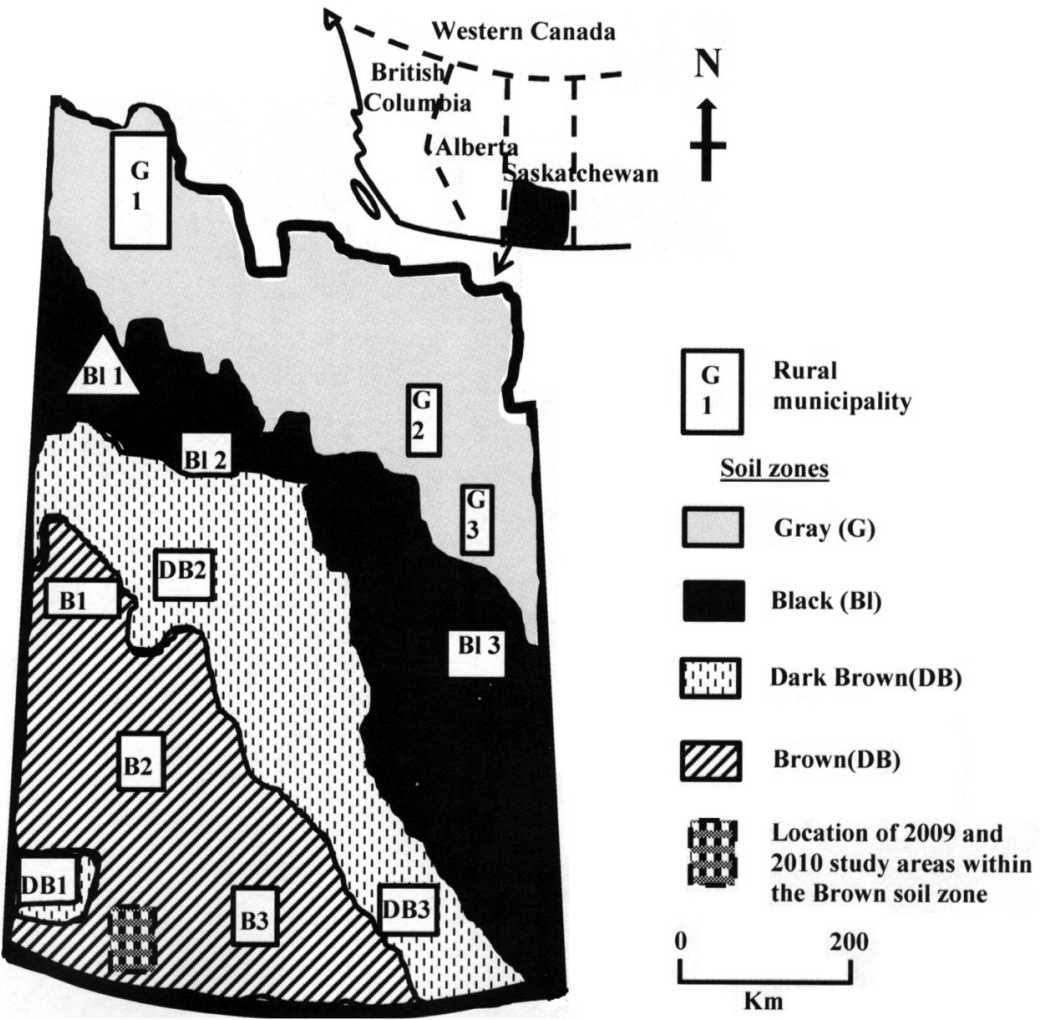

FIGURE 1. Location of study areas in 2008, 2009 and 2010 in Saskatchewan.

south of $54^{\circ} \mathrm{N}$ and is confined to $265691 \mathrm{~km}^{2}$, or $40.8 \%$ of the land mass of Saskatchewan (Harrison 2000*). We conducted our study in four soil zones (Figure 1), from the southernmost Brown soil zone, with warm temperatures, lack of moisture, and lack of organic matter, to the most intensively cultivated Dark Brown soil zone, the productive Black soil zone with high moisture levels, and the cooler Gray soil zone (including graywooded soils) with a shorter growing season (Harrison 2000*).

There were insufficient data in 2008 to allow a thorough assessment of the impact of vegetation height on Richardson's Ground Squirrel population densities. This assessment was therefore continued in 2009 and 2010, within the Brown soil zone only, in grasslands near the towns of Kincaid, Hazenmore, Aneroid, Ponteix, and Cadillac, in southwestern Saskatchewan (Figure 1).

Study plots corresponded to mixed grasslands of Crested Wheatgrass (Agropyron cristatum), brome (Bromus spp.), Slender Wheatgrass (Elymus trachycaulus), and alfalfa (Medicago spp.). Vegetation $\geq 15 \mathrm{~cm}$ in height interferes with the sight lines of Richardson's Ground Squirrels walking or feeding on the surface (Proulx, unpublished data). We therefore located study areas in grasslands with short (on average, $<15 \mathrm{~cm}$ ) and tall (on average, $\geq 15 \mathrm{~cm}$ ) vegetation that were adjacent to each other, i.e., with borders touching each other or separated by a gravel road within the same quarter section. Grasslands with tall vegetation had not been grazed for more than two years, except in Aneroid, where the grassland was subject to short periods (i.e., seven days) of rotational grazing, but vegetation was always $\geq 15 \mathrm{~cm}$ high.

\section{Methods}

Distribution of Richardson's Ground Squirrels according to soil zone

Between 17 May and 15 June 2008, we investigated the distribution and abundance of Richardson's Ground Squirrels. Twelve rural municipalities were randomly selected for field investigations in the four soil zones (Figure 1): three in the Brown soil zone, three in the Dark Brown soil zone, three in the Black soil zone, and three in the Gray soil zone. Since Richardson's Ground Squirrels are more frequent in forage fields and pastures (Provincial Council of Agriculture Development and Diversification Boards and Saskatchewan Agriculture and Food 2001*), we selected three hayfields or pastures in each rural municipality where farmers had complained to local administrators about high densities of Richardson's Ground Squirrels. In each field, we estab- 
lished one study plot of $70 \mathrm{~m} \times 70 \mathrm{~m}(0.49 \mathrm{ha})$ in the southwest corner. In total, 36 study plots (9 per soil zone) were inventoried.

We determined relative densities of Richardson's Ground Squirrels with visual counts, i.e., using binoculars, we recorded the number of adult Richardson's Ground Squirrels in each study plot in three scans of 3 minutes each separated by an interval of 5 minutes (Bourne et al. 2002; Johnson-Nistler et al. 2005). We initiated surveys after sunrise and completed them before 1000 hours every morning. To minimize the number of variables affecting counts, the same observer, situated approximately $25 \mathrm{~m}$ from the border of the study plot, conducted all the scans. The scans were conducted under similar environmental conditions from day to day to avoid a variation in Richardson's Ground Squirrel activity associated with weather (Bourne et al. 2002). For each study plot, we retained the highest number of Richardson's Ground Squirrels counted among the three scans (Fagerstone 1984).

We also counted the number of Richardson's Ground Squirrel burrow entrances located within $30 \mathrm{~cm}$ of each side of the perimeter of the study plots. Only entrances that were well opened and without collapsed dirt or vegetation growing in the entrance were counted (Schmutz and Hungle 1989; Finger et al. 2007*). Therefore, for each study plot, we tallied burrow entrances along a transect $280 \mathrm{~m}$ in length.

Densities of Richardson's Ground Squirrel burrow entrances according to vegetation height

We carried out field investigations from 5 to 20 May 2009, when all adult Richardson's Ground Squirrels had emerged and most juveniles had not yet emerged, and from 15 to 28 May 2010, when all adults and many juveniles were active above ground. We selected five study areas where grasslands with short and tall vegetation were adjacent to each other. We used the average of 15 measurements taken randomly across grasslands to classify the vegetation as short $(<15 \mathrm{~cm})$ or tall $(\geq 15 \mathrm{~cm})$. We established three study plots of 0.49 ha each in each grassland. The study plots were equidistant from each other and from the border of the grassland; they were $>10 \mathrm{~m}$ from the borders of the grassland, and each study plot was $\geq 10 \mathrm{~m}$ from the other two study plots.

Because we were able to establish a strong correlation between visual counts of Richardson's Ground Squirrels and counts of burrow entrances in the study, we proceeded to compare the density of Richardson's Ground Squirrels among grasslands with the number of burrow entrances $/ 0.49$ ha. Burrow entrances were inventoried by five people walking $5 \mathrm{~m}$ abreast up and down study plots. For each grassland, we averaged the number of burrow entrances in the three study plots.

\section{Data analyses}

We used analyses of variance followed by a Tukey's honestly significant difference test to compare mean densities of Richardson's Ground Squirrels and burrow entrances between soil zones (Zar 1999). For 2008, because of the small number of study plots with vegetation $\geq 15 \mathrm{~cm}$ high, the sole influence of vegetation height, i.e., without the influence of soil, on the abundance of Richardson's Ground Squirrels could not be determined. Independent of the soil zone, the mean density of burrow entrances in grasslands with vegetation $<15 \mathrm{~cm}$ high was compared to the mean density of burrow entrances in grasslands with vegetation $\geq 15 \mathrm{~cm}$ high with a Student $t$-test (Dixon and Massey 1969).

For 2009 and 2010, we also compared the mean densities of Richardson's Ground Squirrel burrow entrances/ 0.49 ha in grasslands with short vegetation and grasslands with tall vegetation. However, field observations indicated that Richardson's Ground Squirrel population densities varied considerably within the Brown soil zone, i.e., a low density of Richardson's Ground Squirrels within one quarter section can be considered high in another one (Proulx, unpublished data). For this reason, paired sample $t$-tests were also used to compare the mean densities of Richardson's Ground Squirrel burrow entrances/0.49 ha in adjacent grasslands with short and tall vegetation (Zar 1999). Each datum in a study plot with short vegetation was correlated with only one datum in a study plot with tall vegetation.

Simple linear regression models were used to determine the relationship between counts of burrow entrances and visual counts of Richardson's Ground Squirrels, and between counts of burrow entrances and vegetation height. Probability values $P \leq 0.05$ were considered significantly different.

\section{Results}

Distribution of Richardson's Ground Squirrels according to soil zone

The average number of Richardson's Ground Squirrels/ 0.49 ha differed significantly $\left(F_{3,32}=4.02, P<0.05\right)$ among soil zones. Average densities of Richardson's Ground Squirrels were similar $(P>0.05)$ in the Brown and Black soil zones (Figure 2). However, the average number of Richardson's Ground Squirrels/ 0.49 ha in the Brown soil zone was significantly $(P<0.05)$ higher than in the Gray and Dark Brown soil zones. There was no significant difference $(P>0.05)$ between the average numbers of Richardson's Ground Squirrels/ 0.49 ha in the Black, Gray, and Dark Brown soil zones (Figure 2).

The average number of Richardson's Ground Squirrel burrow entrances $/ 280 \mathrm{~m}$ of transect differed significantly $\left(F_{3,32}=3.3, P<0.05\right)$ among soil zones. The mean number of entrances was significantly $(P<0.05)$ greater in the Brown soil zone than in the other soil zones (Figure 3). The mean number of entrances was also significantly $(P<0.05)$ greater in the Black soil zone than in the Gray soil zone. The mean number of entrances/280 m of transect in the Dark Brown soil 


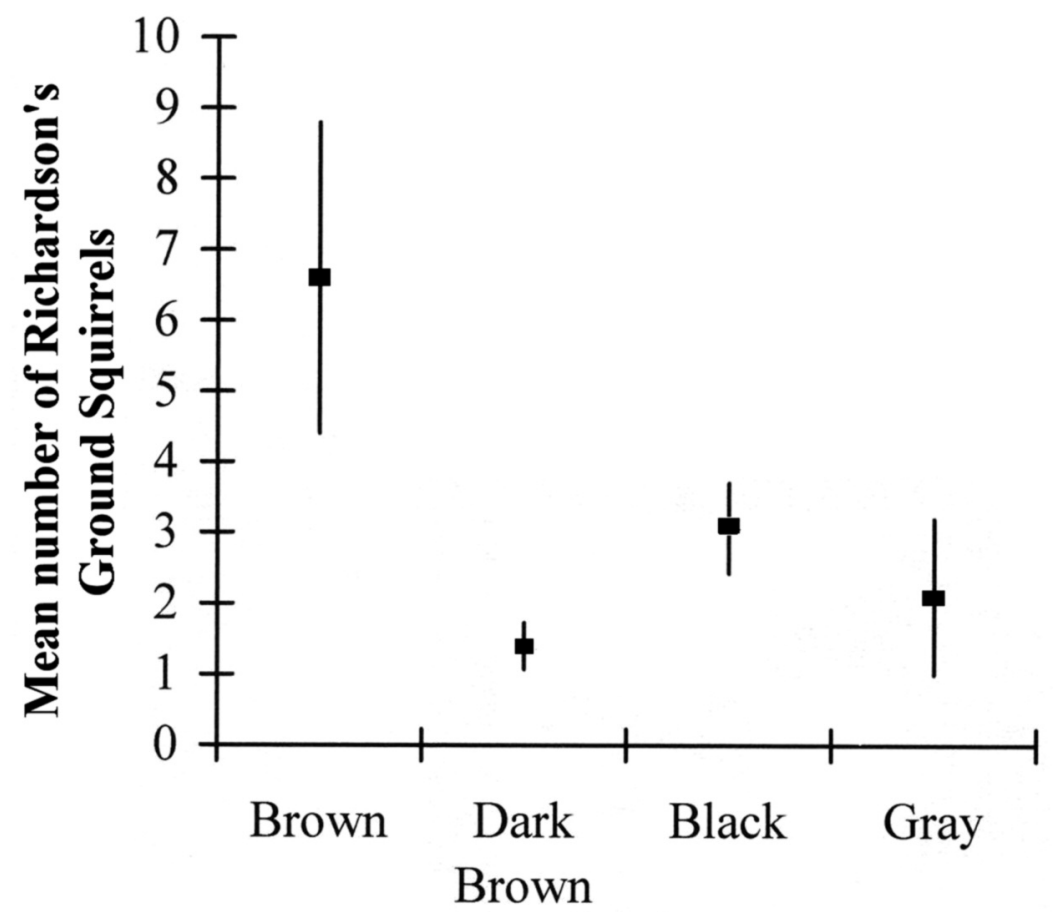

\section{Soil zones}

FIGURE 2. Mean number (bars indicate the standard error) ( $n=9$ study plots/soil zone) of adult Richardson's Ground Squirrels/ 0.49 ha study plot, in four soil zones of Saskatchewan, spring 2008.

zone was similar $(P>0.05)$ to those in the Black and Gray soil zones (Figure 3).

A significant linear $(n=36, r=0.93, P<0.001$; statistical power: 1.0$)$ relationship $(y=3.680+4.021 x$; $r^{2}=0.86$ ) existed between visual counts of Richardson's Ground Squirrels and counts of burrow entrances (Figure 4).

Visual and burrow entrance counts vs. vegetation height in 2008

Seven study plots had a vegetation height $\geq 15 \mathrm{~cm}$ : 2 in the Brown soil zone, 4 in the Dark Brown soil zone, and 1 in the Black soil zone. The other 29 study plots in the four soil zones had a vegetation height $<15 \mathrm{~cm}$. The average number of Richardson's Ground Squirrels/ study plot with vegetation $\geq 15 \mathrm{~cm}$ high $(\bar{x}=1.1$ animals, SD 1.1) was significantly $(t=3.11, P<0.005)$ smaller than that of study plots with vegetation $<15$ $\mathrm{cm}$ high $(\bar{x}=3.8$ animals, SD 4.1). The average number of Richardson's Ground Squirrel burrow entrances/ $280 \mathrm{~m}$ of transect in study plots with vegetation $\geq 15$ cm high $(\bar{x}=9.1$ entrances, SD 6.7) was significantly $(t=2.36, P<0.05)$ smaller than in study plots with vegetation $<15 \mathrm{~cm}$ high $(\bar{x}=18.9$ entrances, $S D 17.7)$.
Burrow entrance counts vs. vegetation height in 2009 and 2010

On average, the number of Richardson Ground Squirrel burrow entrances/0.49 ha was significantly higher in grasslands with vegetation $<15 \mathrm{~cm}$ high $(n=5$, $\overline{\bar{X}}=243.7$ entrances, SD 104.6) than in grasslands with vegetation $\geq 15 \mathrm{~cm}$ high $(n=5, \overline{\bar{X}}=95.9$ entrances, SD 69.2). Within paired study plots, the mean density of Richardson's Ground Squirrel burrow entrances was consistently larger ( 1.5 to 7 times) in short vegetation (Table 1). There was a significant mean difference ( $n=5, \overline{\bar{X}}=147.8$, SE 34.4) between the paired densities of Richardson's Ground Squirrel burrow entrances in study plots with short vegetation and in study plots with tall vegetation $(t=4.4, P<0.005)$. A significant linear $(n=10, r=0.7, P<0.05$; statistical power: $0.65)$ relationship $\left(y=294.9-6.7 x ; r^{2}=0.49\right)$ existed between burrow entrance counts and vegetation height (Figure 5).

\section{Discussion}

Short vegetation was found across the agricultural region of Saskatchewan, and Richardson's Ground Squirrel populations were found in all soil zones. How- 


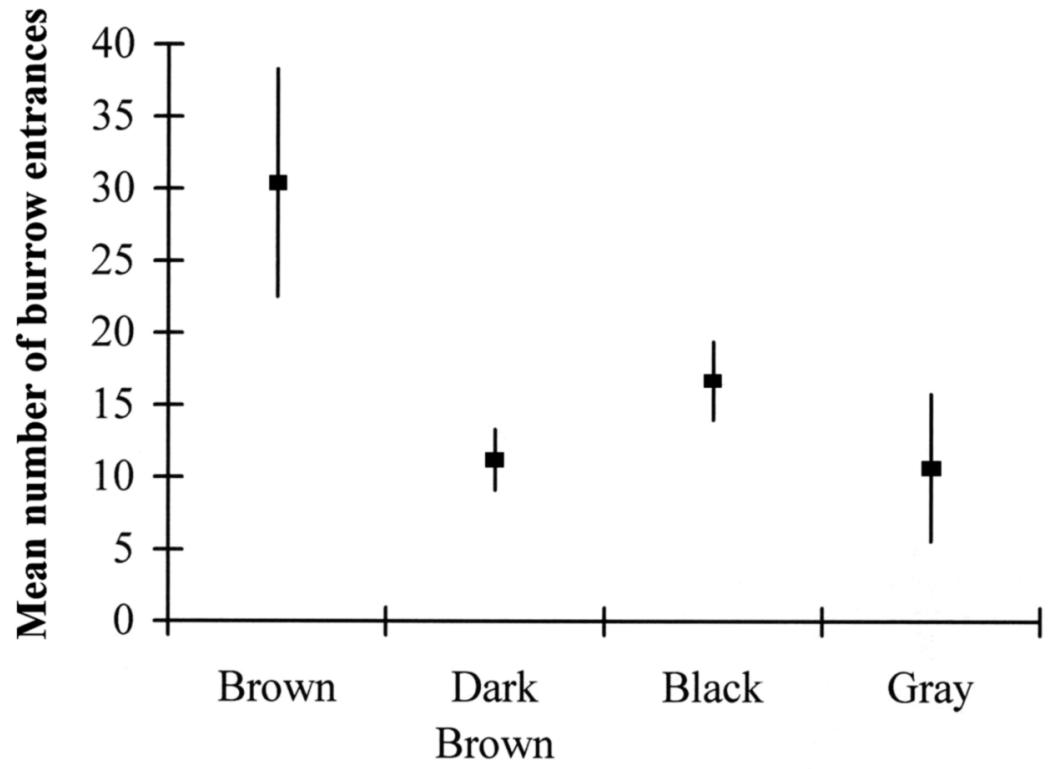

Soil zones

FIGURE 3. Mean number (bars indicate the standard error) ( $n=9$ study plots/soil zone) of Richardson's Ground Squirrel burrow entrances/280 m of survey transect, in four soil zones of Saskatchewan, spring 2008.

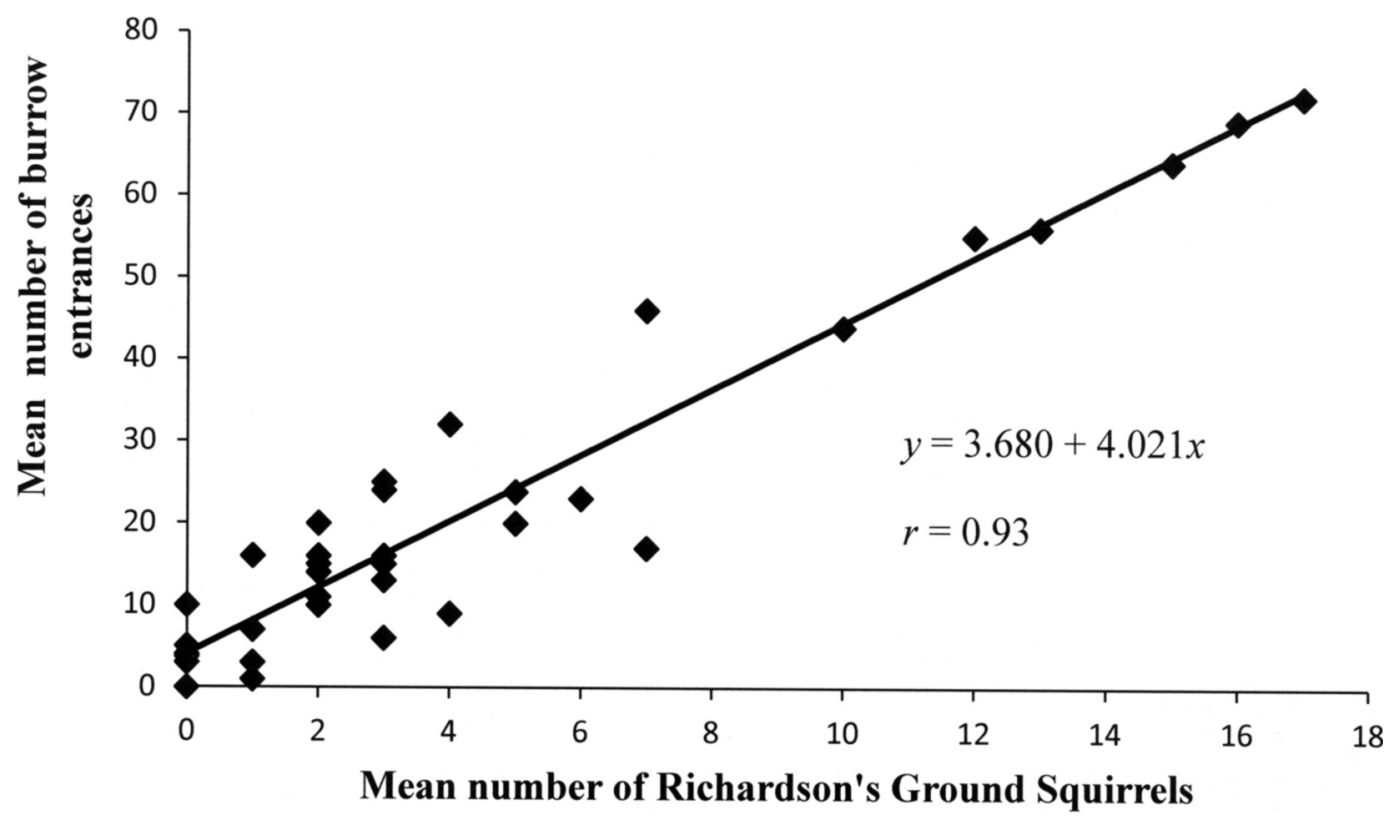

FIGURE 4. Linear regression between the mean number of Richardson's Ground Squirrel burrow entrances/280 m of transect and the mean number of adult Richardson's Ground Squirrels/0.49 ha study plot in the agricultural region of Saskatchewan, spring 2008. 
TABLE 1. Density of Richardson's Ground Squirrel burrow entrances/0.49 ha in grasslands with short vegetation $(<15 \mathrm{~cm})(n=15)$ and tall vegetation $(\geq 15 \mathrm{~cm})(n=15)$, southwestern Saskatchewan, May 2009 and 2010. Standard deviation in parentheses.

\begin{tabular}{|c|c|c|c|c|c|}
\hline \multirow[b]{3}{*}{ Location of grasslands } & \multicolumn{4}{|c|}{ Study plots } & \multirow{3}{*}{$\begin{array}{c}\text { Difference }(d) \\
\text { between mean } \\
\text { densities of } \\
\text { burrow entrances } \\
\pm \text { standard error }\end{array}$} \\
\hline & \multicolumn{2}{|c|}{ Short vegetation } & \multicolumn{2}{|c|}{ Tall vegetation } & \\
\hline & $\begin{array}{l}\text { Mean vegetation } \\
\text { height }(\mathrm{cm})\end{array}$ & $\begin{array}{l}\text { Mean number of } \\
\text { burrow entrances }\end{array}$ & $\begin{array}{l}\text { Mean vegetation } \\
\text { height }(\mathrm{cm})\end{array}$ & $\begin{array}{l}\text { Mean number of } \\
\text { burrow entrances }\end{array}$ & \\
\hline Ponteix & $7.1(1.3)$ & $395(109.1)$ & $15.1(2.4)$ & $173.0(61.7)$ & 222 \\
\hline Aneroid & $7.3(1.2)$ & $197.7(72.00)$ & $24.5(5.1)$ & $53.7(24.9)$ & 144 \\
\hline Hazenmore & $7.6(2.3)$ & $252(28.6)$ & $37.1(4.2)$ & $169.7(38.2)$ & 82.3 \\
\hline Kindaid III & $12.9(4.1)$ & $108.7(52.2)$ & $30.4(8.9)$ & $46.7(30.5)$ & 62 \\
\hline Cadillac & $9.7(3.7)$ & $265(75.7)$ & $35(10.4)$ & $36.3(9.1)$ & 228.7 \\
\hline Grand mean & & $243.7(104.6)$ & & $95.9(69.2)$ & $147.8 \pm 34.4$ \\
\hline
\end{tabular}

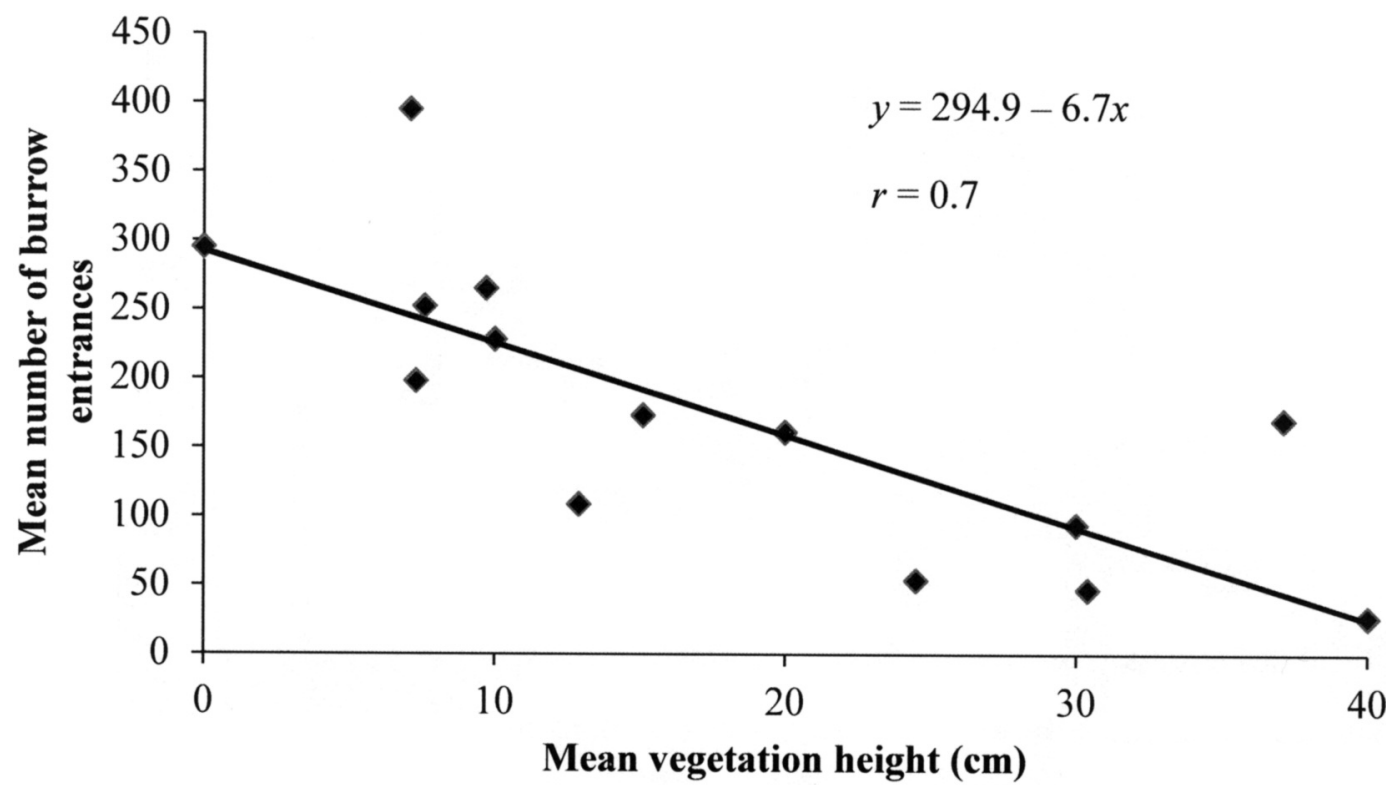

FIGURE 5. Linear regression between the mean number of Richardson's Ground Squirrel burrow entrances/0.49 ha study plot and vegetation height in grasslands of the Brown soil zone of Saskatchewan, May 2009 and 2010.

ever, our findings suggest that Richardson's Ground Squirrels were more abundant in the Brown and Black soil zones, particularly in the former. Our findings relate to a short time period within the drought period, which lasted from 2001 to 2009 (Proulx 2010). Therefore, the distribution and abundance of Richardson's Ground Squirrels across the agricultural region could be different under different environmental conditions. Nevertheless, our findings are in agreement with the findings of the Provincial Council of Agriculture Development and Diversification Boards and Saskatchewan Agriculture and Food (2001*). The abundance of Richardson's Ground Squirrels in the Brown soil zone is well known (Wilk and Hartley 2008*) and has been consistently associated with the characteristic drought periods of the prairies (Isern 1988).
Our field observations from 2008 suggested a difference in the densities of Richardson's Ground Squirrels associated with vegetation height, i.e., lower densities when vegetation height was $\geq 15 \mathrm{~cm}$. It could be argued that it was more difficult to detect Richardson's Ground Squirrels in fields with tall vegetation than in fields with shorter vegetation, but burrow entrance counts supported our visual counts. Because many factors have an impact on Richardson's Ground Squirrel population densities within a single soil zone, namely predation (Proulx and MacKenzie 2012) and agricultural practices (Proulx 2010; Proulx et al. 2010), vegetation height explained only $50 \%$ of the total variation in the relative density of Richardson's Ground Squirrel burrow entrances. Therefore, pairing adjacent fields with different vegetation heights was necessary to assess the 
impact of vegetation height on local populations that are subject to similar environmental conditions.

When vegetation is taller, Richardson's Ground Squirrel populations may not disappear, but their densities are significantly lower. Although the densities of burrow entrances recorded in study plots are not absolute estimates of Richardson's Ground Squirrel population densities (e.g., Van Horne et al. 1997), our analyses suggest that there is a positive relationship between the number of burrow entrances and the number of animals. Even with a maximum ratio of 10 burrow entrances per individual Richardson's Ground Squirrel (Berentsen and Salmon 2001; Michener $2007^{*}$ ), an average difference of 148 burrow entrances/ 0.49 ha between study plots with low and high vegetation would imply a much higher level of occupancy by Richardson's Ground Squirrels in quarter sections (160 ha) with vegetation $<15 \mathrm{~cm}$ high.

Persistence of burrow entrances from the previous year could lead to an overestimation of densities (Van Horne et al. 1997). On the other hand, since all the study plots were located in the same quarter sections and were subject to similar environmental conditions, the relative persistence of entrances would be similar among study plots. Contrary to other studies (e.g., Van Horne et al. 1997), the burrow entrances of Richardson's Ground Squirrels in our study area could be reliably distinguished from those used by other small mammals, because there were no other species that would dig burrow entrances similar to those of the Richardson's Ground Squirrel. In 2009, our surveys missed the peak of juvenile activity and the resulting increase in the digging of burrow entrances. In 2010, the increase in burrow entrances likely reflected the presence of juveniles, but such an increase would have occurred proportionally with the original breeding population of all study plots.

Richardson's Ground Squirrels prefer fields with shorter vegetation and good visibility (Yensen and Sherman 2003), and dry soil types are associated with poor vegetation growth (Heath et al. 1973). It is therefore not surprising that Richardson's Ground Squirrels were more abundant in the relatively drier Brown soil zone, particularly in fields with vegetation $<15 \mathrm{~cm}$ high. However, our findings warrant more studies on Richardson's Ground Squirrels that inhabit fields with short and tall vegetation to determine whether differences in population densities are due to differences in birth and death rates or immigration and emigration.

\section{Acknowledgements}

We thank the Saskatchewan Ministry of Agriculture (Agriculture Development Fund) for funding the study on the distribution of Richardson's Ground Squirrels in the agricultural region. Funding for the assessment of the effect of vegetation height on Richardson's Ground Squirrel populations in 2009 was provided by Advancing Canadian Agriculture and Agri-Food in Saskatche- wan (as a Collective Outcome Project with Advancing Canadian Agriculture and Agri-Food in Alberta), the Saskatchewan Agriculture Development Fund, and the Saskatchewan Association of Rural Municipalities. Alpha Wildlife Research \& Management Ltd. provided funding in 2010. We thank the administrators of the Rural Municipalities of Stonehenge, Saskatchewan Landing, Kindersley, Lomond, Maple Creek, Harris, Orkney, Great Bend, Paynton, Preeceville, Bjorkdale, and Meadow Lake for facilitating research logistics in their region. We are grateful to the following producers for allowing us to survey their property: O. Balas, R. and N. Bryan, C. and J. Flath, L. Ferguson, G. and M. McKeith, B. McKen, D. and H. MacMillan, W. Masley, M. McLeod, C. McFarlane, S. Near, A. and K. Russell, K. and C. Schuweiler, F. Therrien, and S. Vance. We thank Benjamin Proulx, Kim Stang, Jill Arnott, Christine Korol, and Jessy Dubnyk for technical help. Finally, we thank Pauline Feldstein, Alpha Wildlife Research \& Management Ltd., for reviewing an earlier version of this manuscript.

Documents Cited (marked * in text)

Finger, R., G. J. Wiles, J. Tabor, and E. Cummins. 2007. Washington ground squirrel surveys in Adams, Douglas, and Grant counties, Washington, 2004. Washington Department of Fish and Wildlife, Olympia, Washington.

Harrison, D. 2000. Saskatchewan. Bi-weekly Bulletin (Agriculture and Agri-Food Canada) 13 (15): 1-6.

Michener, G. R. 2007. Burrow system of Richardson's Ground Squirrels (also known as gophers). In Richardson's Ground Squirrels (also known as gophers). By G. R. Michener. University of Lethbridge, Lethbridge, Alberta. http://research.uleth.ca/rgs/burrow.cfm.

Pennock, D. 2005. Field handbook of Saskatchewan soils. By D. Pennock, University of Saskatchewan, Saskatoon. http://www.usask.ca/saskatoon2010/Saskatoon2010/Soil _Judging_Manual_files/Field\%20Handbook\%20for\%20 Saskatchewan\%20Soils\%20(Pennock,\%202005).pdf

Provincial Council of Agriculture Development and Diversity Boards and Saskatchewan Agriculture and Food. 2001. 2001 Saskatchewan "gopher" survey. Report of survey results to Provincial Council of Agriculture Development and Diversity Boards and the Sustainable Production Branch, Saskatchewan Agriculture and Food, Regina, Saskatchewan.

Wilk, C., and S. Hartley. 2008. Management of Richardson's ground squirrel. Agriview 4(2): 7.

\section{Literature Cited}

Berentsen, A. R., and T. P. Salmon. 2001. The structure of California ground squirrel burrows: control implications. Transactions of the Western Section of the Wildlife Society 37: $66-70$.

Bourne, J. B., L. D. Roy, M. Hiltz, P. N. Merrill, and W. Hoffman. 2002. Strychnine baits to control Richardson's ground squirrels: an old story, a new twist. Proceedings of the Vertebrate Pest Conference 20: 11-16.

Dixon, W. J., and F. J. Massey, Jr. 1969. Introduction to statistical analysis. McGraw-Hill Book Company, New York, New York. 
Downey, B. A., P. F. Jones, R. W. Quinlan, and G. J. Scrimgeour. 2006. Use of playback alarm calls to detect and quantify habitat use by Richardson's ground squirrels. Wildlife Society Bulletin 34: 480-484.

Fagerstone, K. A. 1984. An evaluation of visual counts for censusing ground squirrels. Pages 239-246 in Vertebrate Pest Control and Management Materials: Fourth Symposium. Edited by D. E. Kaukienen. ASTM STP 817, American Society for Testing and Materials, Philadelphia, Pennsylvania.

Fuller, L. 2010. Chernozemic soils of the Prairie Region of western Canada. Prairie Soils \& Crops Journal 3: 37-45.

Glickman T. S., Editor. 2000. Glossary of Meteorology. Second edition. American Meteorological Society, Boston, Massachusetts.

Heath, M. E., D. S. Metcalf, and R. F. Barnes. Editors. 1973. Forages: the science of grassland agriculture. Third edition. Iowa State University Press, Ames, Iowa.

Helgen, K. M., F. R. Cole, L. E. Helgen, and D. E. Wilson. 2009. Generic revision in the Holarctic ground squirrel genus Spermophilus. Journal of Mammalogy 90: 270-305.

Isern, T. D. 1988. Gopher tales: a study in western Canadian pest control. Agricultural History Review 36(2): 188-198.

Johnson-Nistler, C. M., J. E. Knight, and S. D. Cash. 2005. Considerations related to Richardson's ground squirrel (Spermophilus richardsonii) control in Montana. Agronomy Journal 97: 1460-1464.

Liu J., R. E. Stewart, and K. Szeto. 2004. Moisture transport and other hydrometeorological features associated with the severe 2000/01 drought over the western and central Canadian prairies. American Meteorological Society 17: 305-319.

Phillips, D. W. 2002. The top ten Canadian weather stories for 2001. CMOS Bulletin 30: 19-23.
Proulx, G. 2010. Factors contributing to the outbreak of Richardson's ground squirrel populations in the Canadian prairies. Pages 213-217 in Proceedings of the 24th Vertebrate Pest Conference, Sacramento, California, February 22-25, 2010. Edited by R. M. Timm and K. A. Fagerstone. University of California, Davis, Davis, California.

Proulx, G., and N. MacKenzie. 2012. Relative abundance of American badger (Taxidea taxus) and red fox (Vulpes vulpes) in two landscapes with high and low rodenticide poisoning levels. Integrative Zoology 7: 41-47.

Proulx, G., N. MacKenzie, K. MacKenzie, K. Walsh, B. Proulx, and K. Stang. 2010. Strychnine for the control of Richardson's ground squirrels: efficiency and selectivity issues. Pages 125-128 in the Proceedings of the 24th Vertebrate Pest Conference, Sacramento, California, February 22-25, 2010. Edited by R. M. Timm and K. A. Fagerstone. University of California, Davis, Davis, California.

Schmutz, J. K., and D. J. Hungle. 1989. Populations of ferrugiunous and Swainson's hawks increase in synchrony with ground squirrels. Canadian Journal of Zoology 67: 2596-2601.

Van Horne, B., R. L. Schooley, S. T. Knick, G. S. Olson, and K. P. Burnham. 1997. Use of burrow entrances to indicate densities of Townsend's ground squirrels. Journal of Wildlife Management 61: 92-101.

Yensen, G. E., and P. W. Sherman. 2003. Ground squirrels: Spermophilus and Amnospermophilus species. Pages 211231 in Wild mammals of North America: Biology, Management, and Conservation. Edited by G. A. Feldhamer, B. C. Thompson, and J. A. Chapman. Johns Hopkins University Press, Baltimore, Maryland.

Zar, J. H. 1999. Biostatistical Analysis. Fourth edition. Prentice Hall International, Upper Saddle River, New Jersey.

Received 6 October 2011

Accepted 17 March 2012 